\title{
Pengolahan dan Uji Kualitas Pupuk Organik Feses Sapi (Bos taurus) dan Enceng Gondok (Eichhornia crassipes) terhadap Pertambahan Tanaman
}

\author{
Mimatun Nasihah ${ }^{*}$, Istianah ${ }^{2}$, Lilik Mujiati $^{2}$ \\ ${ }^{1}$ Dosen Program Studi Kesehatan Lingkungan Universitas Islam Lamongan \\ ${ }^{2}$ Mahasiswa Program Studi Kesehatan Lingkungan Universitas Islam Lamongan \\ *Correspondence author: mima@unisla.ac.id ; Tel.: 082331602188
}

Received: 1 Agustus 2019; Accepted: 26 September 2019; Published: 28 September 2019

\begin{abstract}
Usually, the people of Mojopetung Village, Dukun Subdistrict, Gresik Regency in disposing of waste from livestock are left idle in the ground if dried cow feces will be dumped into the rice fields. If in the rainy season the cattle fases will disappear by itself because it is carried by running water and the cow feces seep into will also flow into the river directly. This causes the water to not function properly and cause air and soil pollution. In addition, aquatic biota life is also disturbed not only because of cow feces (Bos taurus) but the existence of Eichhornia crassies which continue to increase people's habit does not use water as they should use as a place of animal baths. These problems can be overcome by processing cow feces with water hyacinth as compost. With the method of applying the fertilizer directly to plant. The method of data analysis was carried out using one-way ANOVA (Analysys of Variance) Test to find out whether or not the influence of organic fertilizer on plant growth. The results showed that the average height of the stem was $32.69 \mathrm{~cm}$ in the treatment using compost, $30.84 \mathrm{~cm}$ using urea fertilizer, $25.8 \mathrm{~cm}$ without fertilizer. The number of leaves that use compost, urea or no fertilizer results in an average value equal to $5 \mathrm{~cm}$, and the leaf color produces a green average for each experiment. ANOVA test on plant growth results in $F=14.608>$ $F$ table $=3.59$. this shows that there are significant differences in plant growth in organic fertilizer applications. the number of leaves and the color of the leaves yielded $F=0<F$ arithmetic $=3.59$ and $F=0.2<F$ arithmetic $=3.59$ which showed no significant difference in the number of leaves and plant height.
\end{abstract}

Keywords: Cow Feces, Eichhornia crassipes, Compost Fertilizer, Plant Growth 


\section{Pendahuluan}

Usaha peternakan mempunyai prospek untuk dikembangkan karena tingginya permintaan akan produk peternakan. Usaha peternakan juga memberi keuntungan yang cukup tinggi dan menjadi sumber pendapatan bagi banyak masyarakat di perdesaaan di Indonesia. Sebagai contoh di Desa Mojopetung, Kecamatan Dukun, Kabupaten Gresik merupakan sebuah desa yang sebagian besar penduduknya adalah terdiri dari peternak, petani seperti peternak sapi, kambing dan ayam. Dari keseluruhan masyarakat di sana sebagian besar mata pencaharian penduduknya adalah $30 \%$ terdiri dari peternak, 50\% sebagai petani, 15\% masyarakatnya yang berprofesi sebagai pengusaha dan guru dan hanya $5 \%$ yang tak bekerja (1).

Limbah kotoran sapi adalah salah satu jenis limbah yang dihasilkan dari kegiatan peternakan. Limbah ini mempunyai andil dalam pencemaran yang sering menimbulkan masalah lingkungan yang mengganggu kenyamanan hidup masyarakat sekitar karena limbah kotoran sapi di desa Mojopetung kebanyakan peternak hanya membiarkan kotoran sapi tersebut berada di atas tanah atau berada di dalam karung. Gangguan tersebut berupa bau yang tidak sedap yang ditimbulkan oleh gas, terutama gas amoniak (NH3) dan gas Hidrogen Sulfida (H2S). Kedua gas tersebut dalam konsentrasi tertentu akan mengganggu ternak dan peternaknya. Ternak yang menghirup kedua gas tersebut akan mengalami gangguan pada saluran pernafasan yang mengakibatkan ternak menjadi lebih peka terhadap serangan penyakit dan apabila hujan maka kotoran terebut sedikit demi sedikit akan larut dengan air kemudian mengalir ke sungai dan dapat menjadi pencemaran air sehingga kualitas air akan menurun (2).

Namun demikian, sebagaimana usaha lainnya, usaha peternakan juga menghasilkan limbah yang dapat menjadi sumber pencemaran, baik pencemaran tanah air maupun udara Oleh karena itu, seiring dengan kebijakan otonomi, maka pengembangan usaha peternakan yang dapat meminimalkan limbah peternakan perlu dilakukan oleh pemerintah kabupaten atau desa untuk menjaga kenyamanan permukiman masyarakatnya (3).

Sedangkan di waduk desa Mojopetung yang dulu airnya bersih tetapi masyarakat desa tidak menggunakan air tersebut dengan baik tetapi di gunakan untuk tempat pemandian hewan ternak seperti, kambing, kerbau dan sapi. Dari permasalahan tersebut kini di waduk maupun sungai banyak sekali tumbuhnya enceng gondok yang samakin hari semakin menumpuk tanpa adanya solusi menghadapi masalah tersebut (4).

Sehingga dari data tersebut tidak menutup kemungkinan besar resiko pencemaran lingkungan akan terjadi jika masyarakat peternak, petani dan warga setempat tidak bisa memanfaatkan dan mengolah limbah yang di hasilkan. Dari pengolahan limbah hewan ternak, 
hasil pertanian, dan buangan rumah tangga di sungai yang menyebabkan tumbuhnya bluming enceng gondok yang sangat banyak sehingga jika di olah bisa menjadi sumber penghasilan tambahan bagi pendapatan ekonomi mereka. Sebagaimana yang biasa terjadi juga kebanyakan masyarakat yang berada di pedesaan semuanya menyatu dengan kegiatan-kegiatan yang ada kaitannya dengan pertanian secara luas kerena memang itulah keahlian mereka yang dapat digunakan untuk mempertahankan kehidupannya. Tidak heran seorang petani selain mengolah sawahnya, mereka juga memelihara ternak misalnya ternak bebek, ayam kampung atau yang sering dikenal ayam buras, ada juga yang memelihara kambing atau sapi (5).

Dari uraian latar belakang masalah di atas perlu dilakukan suatu penelitian yaitu Enceng gondok yang semakin banyak di perairan dan feses sapi yang terbuang sia-sia di sembarang tempat adalah permasalahan yang harus diatasi. Salah satu upaya dalam hal tersebut itu adalah dengan memanfaatkan limbah peternakan dan eceng gondok sehingga dapat memberi nilai tambah bagi usaha masyarakat tersebut.

\section{Materials and Methods}

Penelitian ini termasuk dalam penelitian eksperimental dengan skala lapangan, dengan memberikan perlakuan (treatment) terhadap objek penelitian serta adanya kontrol penelitian.

\section{Desain Penelitian}

Penelitian yang dilakukan ini hanya melibatkan satu faktor yang berbeda yaitu kosentrasi dari pupuk kompos (Feses sapi dan Enceng gondok), Pupuk Urea sedangkan faktor lain dibuat tetap dan seragam. Perlakuan diatur dengan pengacakan secara lengkap sehingga setiap satuan percobaan memiliki peluang yang sama untuk mendapat setiap perlakuan. Dalam percobaan ini terdapat 3 perlakuan dan 5 pengulangan, perlakuan yang diberikan adalah:
A. Tanaman (Pupuk kompos feses sapi dan enceng gondok)
B. Tanaman (Pupuk Urea)
C. Tanaman (Tanpa Pupuk)

Tabel 1. Alat dan Bahan

\begin{tabular}{lll}
\hline NO & ALAT & BAHAN \\
\hline $\mathbf{1}$ & Polybag & Urea \\
\hline $\mathbf{2}$ & Sekop kecil & Pupuk Kompos \\
\hline $\mathbf{3}$ & Penghalus Enceng gondok & Bibit tanaman
\end{tabular}




\begin{tabular}{lll}
\hline & Vol. 3 No. 2 Tahun 2019 Page 27-35 \\
Article \\
\hline $\mathbf{4}$ & Bak kecil & \\
\hline $\mathbf{5}$ & Karung & Air \\
\hline $\mathbf{6}$ & Plastik & Tanah \\
\hline $\mathbf{7}$ & Bak & Enceng gondok \\
\hline $\mathbf{8}$ & Alat tulis & Feses sapi \\
\hline $\mathbf{9}$ & & EM4 \\
\hline $\mathbf{1 0}$ & & Tetes tebu \\
\hline
\end{tabular}

\section{Pelaksanaan Penelitian}

\section{A. Persiapan media tanaman}

1. Pada lokasi pengambilan tanah di Desa Mojopetung kecamatan Dukun Kabupaten Gresik. Tanah diambil dari sawah kemudian di bawa ke rumah Jl. KH. Hasyim Asyari RT 08 RW 03

2. Perbandingan yang di gunakan antara pupuk kompos, pupuk urea dan tanpa pupuk sebanyak 3 kali pengulangan

3. Tanah di masukan ke dalam wadah masing - masing wadahberisi pupuk yang berbeda

4. Tanah disetiap wadah disiram dengan air dan dijaga kelembapannya

\section{B. Persiapan benih}

Bahan tanaman yang diuji adalah tanaman kacang hijau (Vigna radiata)

\section{Penanaman}

Benih tanaman kacang hijau (Vigna radiata) sebelum ditanam di rendam terlebih dahulu di dalam air selama 15 menit, benih yang sudah tenggelam segera ditanam langsung di gelas. Benih yang sudah mengapung, perendaman di lanjutkan sampai dengan 5 menit baru ditanam di polybag dengan kedalaman $\pm 1 \mathrm{~cm}$, setiap gelas diisi 3 benih. Langkah ke dua memasungkan pupuk kompos dan Urea ke dalam gelas Tanaman yang dipilih adalah tanaman yang mempunyai pertumbuhan terbaik.

\section{Pemeliharaan tanaman}

1. Penyiraman. Penyiraman dilakukan setiap hari dengan menggunakan air untuk menjaga kelembapan tanah

2. Mengamati pertumbuhan

3. Pengendalian hama dan penyakit. Pemantauan hama dan penyakit tanaman dilakukan tindakan pengendalian jika terjadi serangan. 


\section{E. Pengamatan}

1. Tinggi tanaman. Diukur dengan penggaris, diukur mulai dari permukaan media pada pangkal batang pertama sampai ujung tanaman dihitung pada waktu tanaman berumur 30 hst (hari setelah tanam)

2. Jumlah daun. Jumlah daun dihitung pada waktu tanaman berumur $30 \mathrm{hst}$ (hari setelah tanam)

3. Warna daun. Warna pada daun dilihat jika dalam kondisi sehar berarti daun berwarna hijau

4. Kondisi lingkungan. Kondisi lingkungan tanaman dingin atau panas dilihat selama 30 dan seterusnya.

\section{Analisis Data}

Dalam penelitian uji kualitas pupuk ini menggunakan Analisis uji Anova (Analisys of Varians) Satu Arah.

\section{Hasil penelitian}

Berdasarkan dari hasil penelitian diatas pembuatan pupuk meenggunkan variabel yaitu tanaman enceng gondok, urea, tetes tebu dan EM4, untuk mendapatkan hasil kompos yang baik yaitu dengan melihat perubahannya terutama pada warna, semakin hitam bertandakan kompos ini sudah jadi atau siap untuk digunakan. Dilihat dari data hasil praktikum, tersebut mengalami pembusukan dengan menunjukan perubahan warna tetapi warna dari kedua kompos belum terlihat hitam hanya berwarna coklat, ini mungkin disebabkan substrat yang dipakai hanyalah dedaunan enceng gondok dan feses sapi, selain itu dedaunan yang kami gunakanpun bukanlah dedaunan kering tetapi dedaunan yang masih subur, hijau, seperti. Pada minggu pertama belum terlihat perubahan spesifik dari dedaunan kompos tetapi pada minggu kedua sudah terlihat kondisi pengomposan yaitu dedaunan mulai melayu berwarna coklat muda

Selain warna yang berubah dapat dirasakan aroma kompos yang berbau busuk, dilihat dari peristiwa ini dapat diketahui bahwa kompos ini diuraikan oleh bakteri-bakteri penghasil sulfur yaitu jenis bakteri anaerob yang juga selama proses pengomposanpun wadah dibiarkan tertutup tanpa oksigen, Dari beberapa kondisi yang terlihat, pengomposan tanpa udara/anaerob memacu bakteri-bakteri yang suka tanpa oksigen untuk menguraikan substrat ini dan kerja bakteri suka oksigen terhambat akibatnya bakteri anaerobik ini yang mendominasi dan mereduksi senyawa-senyawa khas beraroma tak sedap. Dari segi ukuran antara sebelum 
pengkomposan dengan yang sudah terlihat perubahan, ini yang mengakibatkan proses pengkomposan terlaksana.

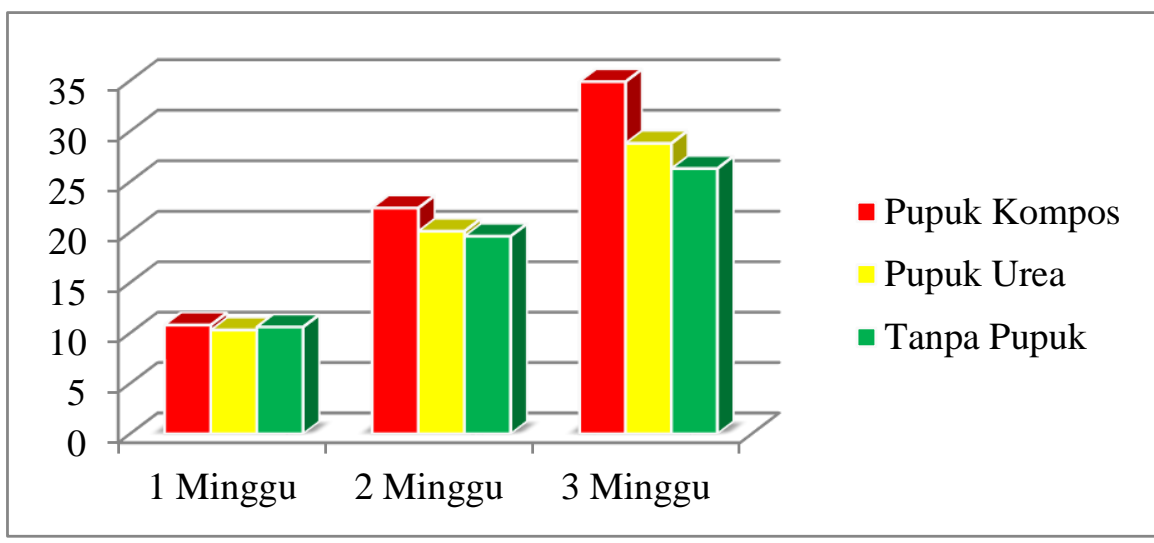

Gambar 1. Laju pertumbuan tinggi batang pada tanaman

Tabel 2. Tabel pengukuran tinggi batang pada hari ke 25

\begin{tabular}{rcc}
\hline 1 PK & 2 PU & 3 TP \\
\hline 32,64 & 30,84 & 25,18 \\
\hline
\end{tabular}

Tabel 3. Uji Anova Pengukuran Tinggi Batang

\begin{tabular}{lrrrrrr}
\hline Source of Variation & \multicolumn{1}{c}{$S S$} & \multicolumn{1}{c}{$d f$} & \multicolumn{1}{c}{ MS } & \multicolumn{1}{c}{ S } & P-value & F tabel \\
\hline Between Groups & 150,292 & 2 & 75,146 & 14,60848 & 0,000609 & 3,59 \\
Within Groups & 61,728 & 12 & 5,144 & & & \\
& & & & & & \\
Total & 212,02 & 14 & & & & \\
\hline
\end{tabular}

Karena $\mathrm{F}=14,608>\mathrm{F}$ tabel $=3,59$ maka H0 ditolak dan HA di terima. Dengan Demikian dapat disimpulkan bahwa rata-rata 3 perlakuan pada masing - masing ulangan berpengaruh secara signifikan terhadap Variabel X dan Y.

Tabel 4. Rata-Rata jumlah daun pada tanaman pada hari ke 25

\begin{tabular}{ccc}
\hline 1 PK & 2PU & 3 TP \\
\hline 5 & 5 & 5 \\
\hline
\end{tabular}




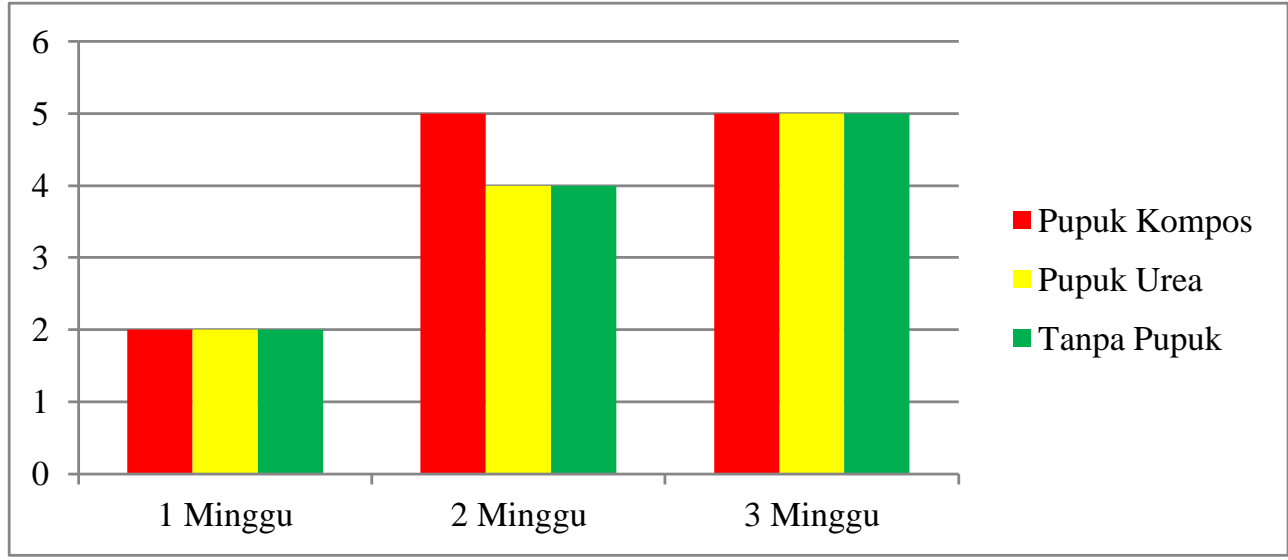

Gambar 2. Laju pertumbuhan daun pada tanaman

Tabel 5. Uji Anova (Analisys of Varians) Satu Arah untuk Tinggi Tanaman

\begin{tabular}{lrrrrrr}
\hline Source of Variation & \multicolumn{1}{c}{$S S$} & \multicolumn{1}{l}{$d f$} & \multicolumn{1}{c}{$M S$} & $F$ & P-value & F tabel \\
\hline Between Groups & 0 & 2 & 0 & 0 & 1 & 3,59 \\
Within Groups & 2,4 & 12 & 0,2 & & & \\
& & & & & & \\
Total & 2,4 & 14 & & & & \\
\hline
\end{tabular}

Karena $\mathrm{F}=0<\mathrm{F}$ hitung $=3,59$ maka H0 diterima dan HA ditolak. Dengan Demikian dapat disimpulkan bahwa rata-rata 3 perlakuan pada masing - masing ulangan tidak ada pengaruh secara signifikan Terhadap Variabel X dan Y.

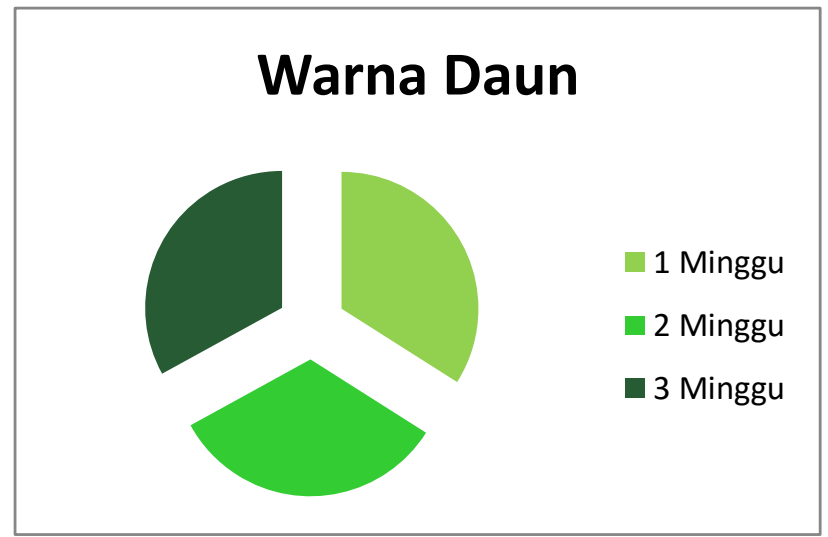

Gambar 3. Laju perubahan warna daun

Tabel 6. Tabel pengamatan perubahan warna daun pada tanaman

$\begin{array}{ccc}1 \text { PK } & 2 \text { PU } & 3 \text { TP } \\ 2 & 2 & 2\end{array}$


Tabel 7. Uji Anova (Analisys of Varians) satu arah untuk warna daun

\begin{tabular}{lrrrrrr}
\hline Source of Variation & \multicolumn{1}{c}{$S S$} & \multicolumn{1}{c}{$d f$} & \multicolumn{1}{c}{ MS } & \multicolumn{1}{c}{ F } & P-value & F Tabel \\
\hline Between Groups & 0,4 & 2 & 0,2 & 0,2 & 0,821405 & 3,885294 \\
Within Groups & 12 & 12 & 1 & & & \\
& & & & & & \\
Total & 12,4 & 14 & & & & \\
\hline
\end{tabular}

Karena $\mathrm{F}=$ 0,2 < F hitung =3,59 maka H0 diterima dan HA ditolak. Dengan Demikian dapat disimpulkan bahwa rata-rata 3 perlakuan pada masing - masing ulangan tidak ada pengaruh secara signifikan Terhadap Variabel X dan Y

Dari percobaan tersebut dapat di lakukan untuk mengetahui pengaruh nutrisi terhadap pertumbuhan dan perkembangan kacang hijau (Vigna radiata) dapat diketahui bahwa pada perkecambahan kacang hijau dengan pemberian jenis pupuk pada masing-masing gelas menunjukan hasil yang berbeda.

Biji kacang hijau ini kami berikan pupuk-pupuk yang berbeda namun dengan takaran yang sama pada masing-masing gelas. Pemberian pupuk hanya dilakukan pada awal penelitian. Jenis pupuk yang kami gunakan antara lain: pupuk kompos, pupuk urea.

Pada gelas A (pupuk kompos) kami tanam 3 biji kacang hijau (Vigna radiata), dengan takaran pupuk 1 sendok makan. Pada botol ini dapat dilihat pertumbuhan kacang hijau pada hari pertama rata-rata tidak tumbuh. Namun hari ke-2 sampai hari ke-5 baru terlihat pertumbuhan secara memadai sekitar $1-8 \mathrm{~cm} /$ hari. Biji kacang hijau (Vigna radiata) yang mampu tumbuh dan ada yang tidak mapu tumbuh dan ada pula yang petumbuhannya agak lambat.

Pada botol B (pupuk Urea) kami tanam 3 biji kacang hijau (Vigna radiata), dengan takaran pupuk 1 sendok. Berdasarkan data hasil eksperimen terlihat pada hari pertama tidak ada terlihat pertumbuhan. Pada hari ke-2 sampai hari ke-5 baru terlihat pertumbuhan. Namun tidak semua biji kacang hijau (Vigna radiate) mampu tumbuh tetapi ada pula yant tidak tumbuh.

Pada botol C (tanpa pupuk) kami tanam 3 biji kacang hijau (Vigna radiate). Pada Gelas ini dapat dilihat dari data pertumbuhan kacang hijau (Vigna radiate) pada hari ke-1 sampai hari ke-2 pertumbuhannya relatif tidak terlalu mencolok. Pertumbuhan yang memadai baru terlihat dari hari ke-3 sampai ke-5 sekitar 1-22 cm/hari.

Dari ketiga pengamatan diatas mendapatkan hasil yang berbeda dari setiap wadah yang berisis pupuk, dan tidak ada perubahan yang signifikan faktor diantaranya, kurangnya lahan 
yang luas, karena penanaman tanaman kacang hijau pada penelitian ini menggunakan wadah yang cukup kecil, suhu udara yang berubah ubah dan kurangnya sinar matahari.

\section{Kesimpulan}

Dari percobaan yang diatas tinggi batang menghasilkan rata rata 32,69 penggunaan pupuk kompos, 30,84 penggunaan pupuk urea, 25,8 tanpa pupuk. Pada jumlah daun dengan pengaplikasian menggunekan pupuk kompos, urea maupun tanmpa pupuk menghasilkan nilai rata- rata yang sama yaitu 5, dan pada warna daun menghasilkan rata - rata warna hijau pada setiap percobaan. Dari data di atas dapat dilihat bahwa pertumbuhan pada tanaman kacang hijau yang diberi pupuk kompos lebih cepat daripada tanaman kacang hijau yang diberi dan urea maupun tanpa pupuk meskipun tidak ada perubahan yang signifikan dikarenakan faktor suhu, udara maupun media tanamnya kurang

\section{Daftar Pustaka}

1. Fr Muhammad. 2016. "Bahan Baku kotoran Sapi" diambil dari http://eprints.polsri.ac.id/3288/3/bab\%202.pdf.

2. Hidayatullah, dkk. 2015. "Usaha Peternakan Sapi Perah Melalui Penerapan Konsep Produksi Bersih". Jurnal Pengakajian dan Pengembangan Teknologi Pertanian. Vol 8 No 1, Maret 2005: 124-136

3. Prihandarini, Ririen. 2004. "Manajemen Sampah, Daur Ulang Sampah Menjadi Pupuk Organik”. Penerbit PerPod. Jakarta

4. Murbandono, L. 2001. "Membuat Kompos”. Edisi Revisi. Jakarta: Penebar Swadaya.

5. Musnawar, E I,. 2003. “ Pupuk Organik; Cair dan padat, pembuatan, Aplikasi” Jakarta: Penebar Swadaya. 